\title{
Training of Applying Research-Based Learning on Junior High School Social Studies Teacher
}

\author{
Nasution Nasution ${ }^{1, *}$ Warsono Warsono ${ }^{2}$ Sarmini Sarmini ${ }^{2}$ Ketut Prasetyo ${ }^{3}$ Nuansa \\ B. Segara ${ }^{2}$ Dian Fauziah ${ }^{2}$ Tri S. Ulamatullah ${ }^{2}$
}

${ }^{1}$ History Education Study Program, Universitas Negeri Surabaya
2 Social Sciences Study Program, Universitas Negeri Surabaya
${ }^{3}$ Geography Education Study Program, Universitas Negeri Surabaya
${ }^{*}$ Corresponding author. Email: nasution@unesa.ac.id

\begin{abstract}
The facts that social studies teachers do not yet have a research culture that focuses on improving the quality of social studies learning and slightly varied learning models used during the learning process lead to the urgency of having a teacher training program on improving teachers' understanding and skills on research-based learning (RBL) model. This paper reports the program implementation of a training program on research-based learning involving twenty-seven social studies teachers as the participants from Nganjuk regency, Indonesia. The method of implementation consists of four stages: 1) needs analysis; 2) preparation; 3) program implementation; and 4) activity of evaluation. The main output of this implementation is the improvement of the participants' understanding of research-based learning. Results showed that the level of understanding, the ability to design RBL learning, the ability to apply RBL in learning at school, and the view of the importance of RBL in learning at school increased at $74 \%, 70.59 \%, 70.59 \%$, and $87.06 \%$, respectively. This means that RBL application training in learning in schools has a positive impact on the ability of teachers to learn and is a critical learning model to be applied. As a recommendation, it is necessary to train RBL learning to broader school scope.
\end{abstract}

Keywords: Junior high school, Research-based learning, Social studies teacher.

\section{INTRODUCTION}

Teachers, as the spearhead of education, need to provide the best service. Innovativeness needs to be done by teachers in developing and improving the quality of learning. According to the Law of the Republic of Indonesia No. 14 of 2021, it is stated that one of the teacher's obligations is to plan to learn, implement a quality learning process, and assess and evaluate learning outcomes. Likewise, in social studies learning, to realize good and quality learning quality, social studies teachers must plan, develop, and evaluate systematically recorded to assess the learning outcomes they are trying to develop. Teachers need to conduct a study that can develop an improvement in the quality of learning in the classroom.

Currently, research conducted by teachers is identical to classroom action research [1]. Many other research methods can be applied in teacher research. Although much training is provided both from academics in universities and school supervisors, the level of the research activity carried out by teachers is still relatively unsatisfactory. In a Classroom Action Research (CAR) training conducted by a team, the training results were not optimal because it only produced CAR proposals from $60 \%$ of participants, $40 \%$ of participants could collect CAR reports, and only 1 participant managed to publish it [2]. Social studies teachers find it challenging to conduct publications and research because there are no ideas for research. The idea does not arise because the culture of reading and writing has not been made something important [3].

Better results are seen in the CAR training conducted for teachers in Sidoarjo Regency. Of the 22 participants who participated, 90\% collected CAR proposals [4]. Other difficulties experienced by Social Studies teachers 
in conducting research are 1) Difficulty in finding theories and books as references for literature review; 2) Do not understand how to quote from primary reference sources, when quoting, the teacher assumes writing word for word in every source encountered so that the level of similarity is high [5]. This happens because teachers have not maximized software for reference management [6]. These obstacles are common when teachers conduct research and also write scientific articles for publication.

Social studies teachers have known various applications of varied research methods, which can be simply applied to improve learning quality. Habituation and cultivating research are carried out so that teachers have the knowledge and skills needed to conduct research. Learning-based research is one thing that teachers do easily because teachers carry out the research base during the learning process. The teacher starts from the learning planning stage and research planning, carries out the learning process in conjunction with the research process, evaluates learning in conjunction with report writing, and the scientific publication process should be carried out through seminars or scientific journals. Because, teachers can do research with reasonable scientific procedures [7]. Furthermore, a key finding in this practice is that to use the potential of research-based learning, participants need to be actively involved in the research process and then implemented directly into research practice [8]. According to Willegems [9], the increased transfer of reflection and inquiry skills acquired through research into everyday teaching practice. Through this RBL-based training activity, teachers will have the opportunity to add insight and experience in reflecting research results into their teaching practice. In this case, the teacher educator, which in this case is the research team, also could conduct RBL-based training based on the collaborative teacher research scheme, where participating teachers can share attitudes regarding collaboration, reflection, inquiry, and student-centred teaching. because this can have been proven to be able to increase the knowledge and skills of teachers in improving the quality of learning [10].

Social studies teachers in Nganjuk Regency also have a similar situation. Learning-based research culture is still limited to promotion purposes only. At the same time, the primary purpose of researching the learning process is to improve the quality of social studies learning. The skills of social studies teachers in Nganjuk Regency in conducting research are still focused on classroom action research (CAR). For this reason, it is necessary to increase understanding of the variations that can be done in conducting learning-based research. Thus, this paper aims to describe the program implementation of a training program on research-based learning for social studies teachers.

\section{METHODS}

Based on the situation analysis and seeing the urgency of the existing problems, the solution from the research team is to provide training in the Application of Research-Based Learning Methods so that teachers have a better understanding, skills, and research skills with varied research methods.

The implementation of community service is carried out in several stages, as shown in the following flow:

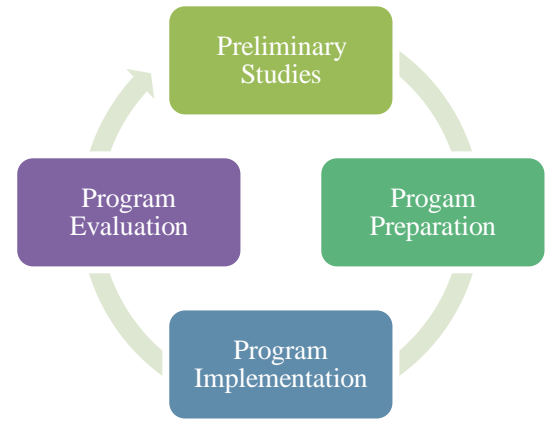

Figure 1 Stages of the Program Implementation.

The implementation of this program consists of four stages: a preliminary study, program preparation, program implementation, and program evaluation. The stages in this series of programs have their characteristics, and there are also differences between the parties involved in this process. The stages in the flow above are described in detail in the following sections:

\subsection{Preliminary Study or Identification of Target Audience}

The team conducted a preliminary study to ascertain exactly what the social studies teachers in Nganjuk needed to conduct research. The research team identified the type of research needed, difficulties in planning research, and writing reports. So with the results of the analysis, the research team made careful preparations.

Based on the analysis of the situation faced by partners and various relevant secondary sources, it can be concluded that some of the problems that partners face are as follows:

a. Teachers do not understand the research-based learning model in its application in Social Studies Learning in Schools.

b. The low variation of the learning model applied in social studies learning at school.

c. The understanding and skills of junior high school social studies teachers in Nganjuk Regency in conducting RBL in the classroom are still inadequate.

The problems faced by partners are counterproductive to teachers' demands during the fast development of the world of education. Technological developments, student characteristics changes, and 
educational research developments need to be anticipated by developing knowledge, skills, and skills so that social studies teachers in Nganjuk Regency can quickly adapt to current actual conditions.

\subsection{Program Preparation}

Preparation is carried out after the needs analysis is carried out. Program preparations carried out are as follows: 1) Technical coordination (location and time) of training with partner teachers in Nganjuk District; 2)
Planning training materials and setting up instructors and facilitators for the internal training of the researchTeam; 3 ) Formulation of training handouts with the research team; 4) Technical discussion of schedule and departure to the training location.

\subsection{Program Implementation}

The program is implemented in two stages, namely in-service and on-job learning. Details can be seen in table 1

Table 1. Implementation Activities

\begin{tabular}{|c|c|c|}
\hline Activity Stage & Activity Procedure & Society participation \\
\hline $\begin{array}{l}\text { In-service } \\
\text { learning }\end{array}$ & $\begin{array}{l}\text { a. Improving the Quality of Learning IPS. Speaker: Drs. } \\
\text { Nasution, M.Hum, M.Ed, Ph.D. } \\
\text { b. Types of research-based learning. Speaker: Prof. Warsono, } \\
\text { c. Planning Study. Speaker: Prof. Dr. Sarmini., M. Hum } \\
\text { d. Research Implementation and Reporting: Dr. Ketut Prasetyo, } \\
\text { M.Sc. } \\
\text { e. Publication of Research Results: Dr. Nuansa Bayu Segara, } \\
\text { M.Pd. }\end{array}$ & $\begin{array}{l}\text { Participants listen, ask } \\
\text { questions, and discuss } \\
\text { with questions and } \\
\text { answers to the } \\
\text { presenters for a deeper } \\
\text { understanding of the } \\
\text { application of research- } \\
\text { based learning. }\end{array}$ \\
\hline $\begin{array}{l}\text { On Job } \\
\text { Learning (2-3 } \\
\text { Weeks) }\end{array}$ & $\begin{array}{l}\text { a. Help plan research by making research proposals. } \\
\text { b. Assist teachers in the preparation of research proposals. }\end{array}$ & $\begin{array}{l}\text { Participants plan } \\
\text { research with the } \\
\text { assistance of the } \\
\text { research Team. }\end{array}$ \\
\hline
\end{tabular}

\subsection{Program evaluation}

This stage is the final stage. Program evaluation is carried out to find out how the target is achieved after program implementation. The evaluation of this program includes the results of an assessment of 1) the usefulness of teachers to the training program; 2) Implementation of workshops; 3) Improved understanding of skills. Furthermore, 4) Output generated during training.

\section{RESULTS}

The in-service-learning program implementation was held on October 2, 2021, at a vocational school in Nganjuk Regency. Twenty-seven teachers attended the implementation of the program. However, only 17 teachers reported the implementation of RBL on the job learning. The following is one of the processes in which one of the resource persons provides material to the training participants.

After implementing the research program in Nganjuk Regency, an evaluation was carried out through a questionnaire to determine the achievements in this training program. There were 22 questions related to identity and understanding of the RBL concept presented at the workshop. The following shows the achievements experienced by social studies teachers in Kab. Nganjuk after attending the training.

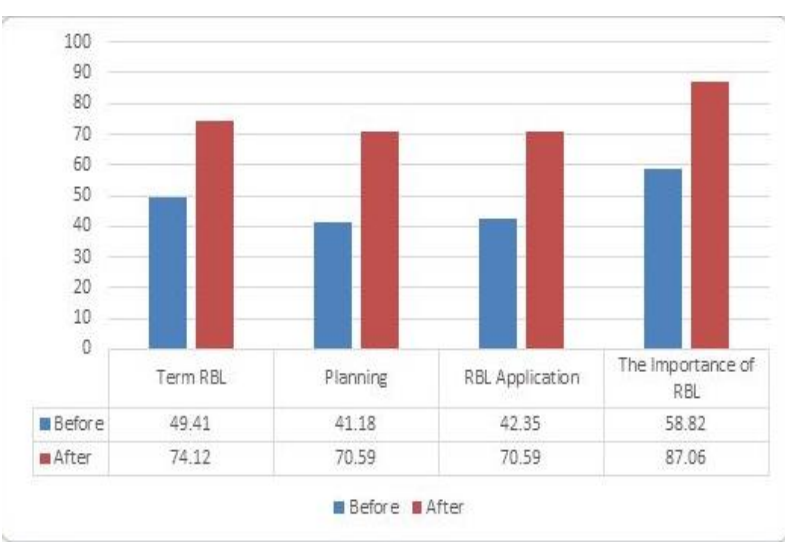

Figure 2 Research-based learning training achievements.

Figure 2 shows several questions related to understanding the concept of RBL. In the graph, "The 
term RBL" is the result of questions that lead to the trainee's understanding of the concept of RBL before and after the training. The results show that the level of understanding of social studies teachers on the term RBL before the training is still not good, while after the training, the level of understanding increases at $74 \%$ and is in the pretty good category.

Meanwhile, when asked whether the teacher could plan RBL lessons before the training, his ability level was only $41.18 \%$, which was poor. Meanwhile, after training, the ability to design RBL social studies teachers can reach up to $70.59 \%$, which is relatively good.

Furthermore, when the teacher was asked about the ability to apply RBL before the training, it was found that the social studies teacher's ability level only reached $42.35 \%$, which means it is still not good. After receiving the training, participants felt they could apply RBL in the classroom with achievement of $70.59 \%$, which was included in the reasonably good category.

The last question relates to the teacher's attitude towards RBL. The teacher was asked what his views were on the importance of RBL for social studies learning. Figure 2 shows the importance of RBL at $58.82 \%$, which means it is considered less critical. Meanwhile, after the training, participants understood the benefits of RBL for students, it increased to $87.06 \%$. This means that according to the teacher RBL is a vital learning model to be applied.

Furthermore, to find out the increase in understanding, planning, and application skills and the importance of RBL before and after training. Table 2 shows a moderate increase in the understanding of social studies teachers on the term RBL. Moderate improvement also occurred in the ability of teachers to plan RBL for classroom learning. Furthermore, there was an increase in the medium category for the teacher's ability to apply RBL.

Table 2. N-Gain Understanding of Research-Based Learning

\begin{tabular}{|c|l|c|c|}
\hline No & \multicolumn{1}{|c|}{ Aspect } & N-Gain & Note: \\
\hline 1 & RBL term & 0.49 & Currently \\
\hline 2 & RBL Planning & 0.50 & Currently \\
\hline 3 & RBL App & 0.49 & Currently \\
\hline 4 & $\begin{array}{l}\text { The Importance of } \\
\text { RBL }\end{array}$ & 0.69 & Tall \\
\hline
\end{tabular}

Finally, there was a high increase in the understanding of social studies teachers related to the implementation of RBL in the classroom between before and after participating in the training. This increase seems to occur because teachers realize that
RBL has advantages that students can utilize. Through RBL, the active learning of students can be accommodated. In addition, RBL is a model that can develop students' critical and systems thinking skills.

The usefulness of the training materials, especially for $\mathrm{RBL}$, received a very positive response. $47.1 \%$ stated that the RBL material was beneficial. Furthermore, $35.3 \%$ said it was helpful. Meanwhile, $11.8 \%$ stated that it was pretty helpful, and $5.9 \%$ said it was not helpful. If it is calculated, the level of usefulness of this RBL material is $84.71 \%$. This figure shows that RBL material has high usefulness for social studies teachers in Nganjuk Regency.

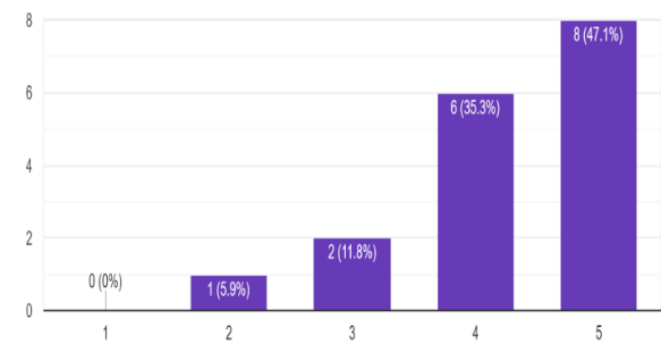

Figure 3 The Benefits of RBL Materials for Participants.

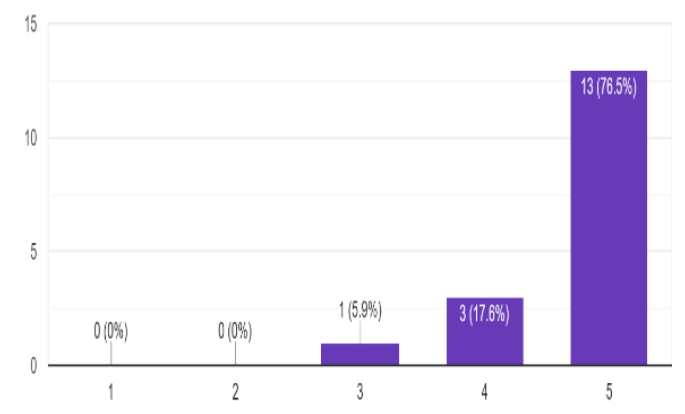

Figure 4 Overall Program Benefit.

Table 3. Description of Figure 4

\begin{tabular}{|c|l|}
\hline No & \multicolumn{1}{|c|}{ Answer Category } \\
\hline 1 & Useless \\
\hline 2 & Less Useful \\
\hline 3 & Quite Useful \\
\hline 4 & Beneficial \\
\hline 5 & Very Helpful \\
\hline
\end{tabular}

Furthermore, Social Studies teachers in Nganjuk Regency were asked questions related to the entire program. This question was asked because to see the general response given after attending the training. Because in this training, not only RBL material is given. However, the basics of the learning paradigm are also thoroughly explained. The public benefit of this program is illustrated in Figure 2. It can be seen that $76.5 \%$ said that, in general, this program was beneficial. 
Furthermore, $17.6 \%$ stated that this training was helpful. Meanwhile, only $5.9 \%$ said it was pretty helpful, and $0 \%$ of the participants said it was more minor and not helpful. These results show that the achievement of program usefulness reaches $94.12 \%$, which means that, in general, the level of usefulness is very high for social studies teachers in Nganjuk Regency.

\section{CONCLUSION}

From the study results, it can be concluded that teachers rarely use RBL in classroom learning. This can be seen from the study results that only half of the respondents did not understand RBL. The implementation of RBL application training for junior high school students who initially received less attention from teachers, after training the teachers realized the importance of implementing RBL in the learning process in schools.

The results of this study recommend the need for similar training to social studies teachers at other schools in Nganjuk Regency.

\section{AUTHORS' CONTRIBUTIONS}

All authors conceived and designed this study. All authors contributed to the process of revising the manuscript, and in the end, all authors have approved the final version of this manuscript.

\section{ACKNOWLEDGMENTS}

We would like to give great appreciation to the Research and Community Service Section (LPPM) and the Graduate School of Universitas Negeri Surabaya for funding this research.

\section{REFERENCES}

[1] T. H. Nurgiansah, Pelatihan penelitian tindakan kelas bagi guru pendidikan kewarganegaraan di sekolah menengah atas se-kabupaten Bantul, BERNAS: Jurnal Pengabdian Kepada Masyarakat 2(1) (2021), 28-33. DOI: https://doi.org/10.31949/jb.v2i1.566.

[2] M. Bili, A. Nasar, M. H. Daud, Y. E. Ika, A. Harso, Pelatihan dan pendampingan penelitian tindakan kelas bagi guru-guru smp rayon Kecamatan Nangapanda, Jurnal Pengabdian Kepada Masyarakat MEDITEG 5(2) (2020) 47-54. DOI: https://doi.org/10.34128/mediteg.v5i2.74

[3] N. Wahyuningtyas, N. Ratnawati, Pelatihan dan pendampingan penulisan artikel jurnal bagi guruguru IPS Kabupaten Malang, Jurnal Praksis Dan
Dedikasi Sosial 1(1) (2018) 39-45. DOI: http://dx.doi.org/10.17977/um032v0i0p40-47

[4] Y. Soesatyo, W.T. Subroto, N. Sakti, M. Edwar, Pelatihan penulisan proposal penelitian tindakan kelas (PTK) bagi guru ekonomi kabupaten sidoarjo, Jurnal Pemberdayaan Masyarakat Madani (JPMM) 1(2) (2017) 162-178. DOI https://doi.org/10.21009/JPMM.001.2.02

[5] A. Wiradimadja, B. Kurniawan, Sukamto, Pelatihan dan pendampingan penyusunan PTK (penelitian tindakan kelas) bagi guru IPS Smp/Mts Malang Raya. Jurnal Praksis Dan Dedikasi Sosial 2(1) (2019) 6-12. DOI: 10.17977/um032v0i0p612

[6] A. Hafid, H. Mukhtar, R. Hayami, Y. Fatma, M. Unik, Peningkatan kualitas publikasi ilmiah dan penelitian bagi guru SLTA dengan pemanfaatan software referensi, Jurnal Pengabdian Untuk $\mathrm{Mu}$ NegeRI 2(2) (2018) 77-82. DOI: 10.37859/jpumri.v2i2.1003

[7] Muhali, M. Asyari, S. Prayogi, T. Samsuri, I. W. Karmana, I. K. Sukarna, B. Mirawati, L. Firdaus, Pelatihan kegiatan penelitian dan penulisan karya ilmiah bagi guru Madrasah Aliyah Negeri 3 Lombok Tengah, Abdihaz: Jurnal Ilmiah Pengabdian Pada Masyarakat 1(1) (2019) 28-36. DOI: https://doi.org/10.32663/abdihaz.v1i1.739

[8] A. Brew, C. Saunders, Making sense of researchbased learning in teacher education, Teaching and Teacher Education, 87, 2020, 102935. DOI: https://doi.org/10.1016/j.tate.2019.102935

[9] V. Willegems, E. Consuegra, K. Struyven, N Engels, Teachers and pre-service teachers as partners in collaborative teacher research: A systematic literature review. Teaching and teacher education, 64, 2017, 230-245.DOI: https://doi.org/10.1016/j.tate.2017.02.014

[10]E. Munthe, M. Rogne, Research based teacher education, Teaching and teacher education, 46, 2015, 17-24 